\title{
Trajectories of Child and Youth Well-Being: Editorial
}

A focus on child and youth well-being is an essential part of every society. Child and youth well-being are a complex set of trajectories, revealing the prospects of opportunities for young people. Challenges in any one of these trajectories can be threats to an individual's success in life. That makes it an important topic that directly affects young people's quality of life. During the COVID-19 pandemic situation, all learners have faced closed schools and have been forced to study online-transitioning from the school classroom to online learning. A significant problem is also deficits in online education participation, especially from children from the most vulnerable families, which could widen the education gap and inequalities. It can potentially pose a risk for children dropping out of the education system. Lack or low level of education is a prerequisite for unemployment and poverty, increased risk of marginalization, and social exclusion. Also, thousands of young people lost their internships and jobs.

The special issue on the „Trajectories of Child and Youth Well-being: Challenges and Perspectives" on the bilingual Journal "Postmodernism problems" represents some of the possible key points related to children and young people's needs and well-being.

Gabriela Neagu, Vladislava Lendzhova and Dilyana Keranova focus on the question of young people who fall into the category NEETs ((Not in Education, Employment or Training). The essence, challenges and changes that occur in modern Bulgarian families are discussed by Todorka Kineva in her article "Problems and Challenges to the Modern Bulgarian Family with Children". Lucien Peters' article "The role of space in the creation of the social capital of Sofia students before the novel coronavirus pandemic", reveals the importance of social capital for young people and its impact on their well-being. "Family Support in the Republic of North Macedonia” by Irena Avirovic Bundalevska, Makedonka Radulovic and Angelka Keskinova focuses on aspects of family support in the Republic of North Macedonia, based on an in-depth analysis of the legal framework of family policies in the country, and identifies practices of organizations working in the field. In the context of the COVID-19 pandemic, Mihaela Racheva addresses the issue of "Media and Communication Strategies Supporting Parents and Children in the COVID-19 Pandemic Environment". Particular emphasis is placed on the importance of supporting parents in the fight against childhood obesity in Bulgaria. Asya Asenova-Todorova in "Aspects of Communication Behavior: Medical Institutions and Public Interest" draws our attention to another aspect related to healthcare. In the context of physical and emotional health, she raises the issue of crisis communication management in the context of medical institutions. 
This issue on the Journal "Postmodernism problems" without claims to comprehensiveness, includes some of the important aspects related to the thousands of interactions between different areas of life of children and young people, and shows the importance of the impact of the environment in which they grow up.

Guest Editors:

Dr. Dilyana Keranova, South-West University "Neofit Rilski," Bulgaria

Dr. Vladislava Lendzhova, South-West University "Neofit Rilski", Bulgaria

Dr. Gabriela Neagu, Research Institute for Quality of Life, Romanian Academy, Romania

\section{Траектории на детското и младежко благосьстояние: редакционна}

Акцентът върху благосъстоянието на децата и младежите е съществена част от живота на всяко общество. Детското и младежкото благополучие са сложна сьвкупност от траектории, разкриваща перспективите от възможности за младите хора. Предизвикателствата в някоя от тези траектории могат да бъдат заплаха за успеха на индивида в живота. Това го прави важна тема, която пряко засяга качеството на живот на младите хора. По време на пандемичната ситуация на COVID-19 всички учащи се сблъскаха със затворени училища и бяха принудени да учат онлайн-преминаха от училищната класна стая към онлайн обучение. Значим проблем се оказаха и дефицитите за участие в онлайн образованието, особено за деца от най-уязвимите семейства. Предизвикателства, които биха могли да увеличат различията в образованието и да допринесат за увеличаване на неравенствата. Всичко това би могло да доведе до увеличаване на потенциалния риск децата да напуснат преждевременно образователната система. От друга страна, липсата или ниското ниво на образование, е предпоставка за безработица и бедност, създава условия за повишен риск от маргинализация и социално изключване. Не по-малко значим проблем са и хиляди млади хора, които загубиха своите възможности за стажовете и работата.

Специалният брой „Траекториите на детското и младежкото благосъстояние: предизвикателства и перспективи“ на двуезичното е-списание „Проблеми на постмодернизма“, представя някои от възможните ключови моменти, свързани с нуждите и благосъстоянието на децата и младите хора.

Габриела Неагу, Владислава Ленджова и Диляна Керанова се фокусират върху въпроса за младите хора, които попадат в категорията NEETs (извън системите на образованието, заетостта и обучението). Същността, предизвикателствата и промените, които се наблюдават в съвременните български семейства, са предмет на научно търсене от 
Тодорка Кинева в статията „Проблеми и предизвикателства пред съвременното българско семейство с деца“. Люсиен Питърс разгрьща въпросът за „Ролята на пространството в изграждането на социален капитал на софийските студенти преди коронавирусната пандемия“" като разкрива значимостта на социалния капитал за младите хора и какво въздействие оказва върху тяхното благосъстояние. „Семейната подкрепа в Република Северна Македония““ от Ирена Авирович Бундалевска, Македонка Радулович и Ангелка Кескинова се фокусира върху аспектите на семейната подкрепа в Република Северна Македония, базирана на задълбочен анализ на правната рамка на семейните политики в страната и идентифицирайки практики на организациите, работещи в тази област. В контекста на пандемията COVID-19, Михаела Рачева разглежда въпроса за „Медийни и комуникационни стратегии в подкрепа на родителите и децата в пандемичната среда COVID-19“. Особен акцент се поставя върху значението на подкрепата на родителите в борбата с детското затльстяване в България. Ася АсеноваТодорова в „Аспекти на комуникационното поведение: лечебни заведения и обществен интерес" насочва вниманието ни към друг аспект, свързан със здравеопазването. В контекста на физическото и емоционалното здраве тя повдига въпроса за управлението на кризисна комуникация в контекста на лечебните заведения.

Настоящият брой на „Проблеми на постмодерността“, без претенции за всеобхватност, включва някои от важните аспекти, свързани с хилядите взаимодействия между различните области от живота на децата и младите хора, и показва значимостта на въздействието на средата, в която те растат.

Гост-редактори:

д-р Диляна Керанова, Югозападен университет "Неофит Рилски", България

д-р Владислава Ленджова, Югозападен университет "Неофит Рилски", България

д-р Габриела Неагу, Изследователски институт за качество на живот, Румънска академия, Румъния 